\title{
MAXIMUM RECESSIONS OF SHALLOW GROUNDWATER LEVEL IN CENTRAL POLAND
}

\author{
PRZEMYSŁAW TOMALSKI \\ Department of Hydrology and Water Management, University of Łódź \\ Narutowicza 88, 90-139 Łódź, Poland \\ tomalski@uni.lodz.pl
}

\begin{abstract}
This article presents a method of describing maximum recessions of groundwater level, drawing on an analysis based on data gathered from 41 sites for the monitoring of groundwater level located in central Poland. Maximum weekly recessions for all of the measurement points were selected, before being employed as a basis for approximating the regression lines used to calculate the theoretical "top speed" recession curves between maximum and minimum groundwater levels, and the estimated time needed for such a recession to be achieved. Studied characteristics of all the examined groundwater recessions were compared with geographical characteristics of the aquifers involved, in order that relations between them could be determined.
\end{abstract}

Key words: groundwater, maximum recessions of water table

\section{INTRODUCTION}

While an understanding of the dynamics to water levels in various aquifers is vital for their management, changes in level unfortunately depend on a wide range of natural and anthropogenic factors, making research a major challenge. One element to groundwater-level dynamics not much researched to date is recession caused by prolonged lack of supply. In fact, the author is familiar with just a few studies addressing the issue in question, e.g. Tomaszewski (1990), Sawicki (1986) and Olin (1995), this doubtless reflecting its complexity, as well as the attendant lack of long-term, reliable data sequences on groundwater levels, in Poland at least. It is nevertheless worth addressing such issues, as they play an important role in shaping the river low-flows that are being studied more and more often, e.g. by Gottschalk et al. (1997), Laaha and Blöschl (2005) and Bartnik (2005).
The process of river low-flow formation entails several stages (Byczkowski 1996), beginning with long-lasting atmospheric drought. The long-term lack of precipitation combines with ongoing river drainage to bring about a gradual reduction in the levels of groundwater reservoirs, this ensuring the progressive development of groundwater drought. A gradual decrease in the flows of rivers draining less and less abundant groundwater ensues, the eventual consequence being low flow. Recognition of groundwater level drainage rates thus allows for the enhancement of knowledge on low-flow development.

Recessions in groundwater levels are a function, not only of unchanging factors like geological structure or size of reservoir, but also of the levels to which a resource is filled. Important factors influencing fluctuations in groundwater level include precipitation, water supply and land management 
practices. At the same degree of filling of a reservoir recessions may be different, depending as they do on impulses of supply determined by rainfall. However, it is possible to establish the maximum recessions in groundwater levels accompanying extremely unfavourable conditions of supply. This characteristic shows the sensitivity of a given reservoir to long-term lack of supply.

\section{STUDY AREA AND DATA}

Analyses drew on data gathered from 41 sites for the monitoring of groundwater levels situated in central Poland (Fig. 1), between the Rivers Warta and Vistula. The data in question are variously-sized sequences of regular (weekly) measurements of groundwater level covering the period 1951-2000. The shortest sequence extends over 33 years of measurement. The data represent all the measurement points in this area for which data sequences are reliable, complete (lacking gaps) and sufficiently long. Prior to analysis, each sequence was checked for homogeneity by means of a series test and an F-Snedecor test. In addition, information was gathered on type of aquifer, degree of isolation from the surface, average depth to the water table and geomorphical position (Table 1).

Isolation from the surface was estimated by reference to the GOD characteristic, as derived by Foster (1987). This procedure was employed primarily in establishing the vulnerability of groundwater to pollution. As the latter depends mostly on the said degree of isolation of aquifers from the surface, the size of the GOD characteristic generates a measure of isolation from the surface (in that limited vulnerability to pollution means a high degree of isolation from the surface, etc.). The GOD procedure is based on type of ground, medium depth to the water table and type of aquifer, and is as described in detail in Foster (1978), as well as used in scientific descriptions (Jokiel 2002).

\section{MAXIMUM RECESSIONS IN GROUNDWATER LEVEL}

Groundwater level can increase or decrease between measurement dates. Further analysis was confined to measurements re-

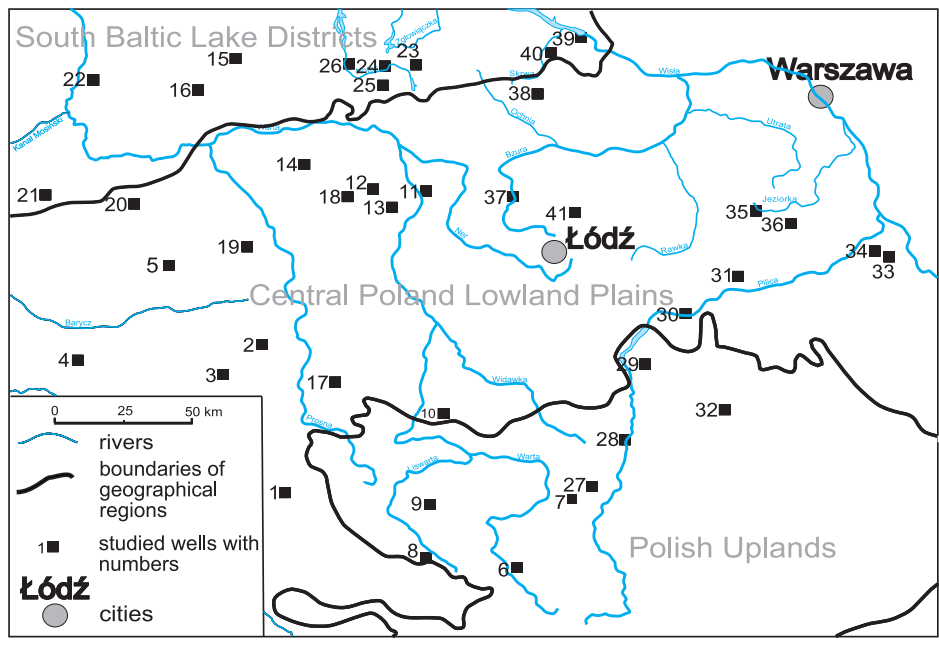

Figure 1. Location of measurement points in relation to the geographical regions of Poland. 
Table 1. Calculated characteristics of maximum recessions of groundwater level

\begin{tabular}{|c|c|c|c|c|c|c|}
\hline No. & $\begin{array}{l}\text { Type of } \\
\text { aquifer }\end{array}$ & $\begin{array}{c}\text { Depth to } \\
\text { water table } \\
{[\mathrm{m}]} \\
\end{array}$ & $\begin{array}{c}\text { Isolation } \\
\text { from } \\
\text { surface }\end{array}$ & $\begin{array}{c}\text { Regression line } \\
\text { for maximum } \\
\text { weekly } \\
\text { recessions } \\
\end{array}$ & $\begin{array}{l}\text { "Top speed" } \\
\text { recession curve }\end{array}$ & $\begin{array}{c}\text { Time of "top } \\
\text { speed" drainage } \\
\text { from maximum } \\
\text { to minimum level } \\
\text { [weeks] }\end{array}$ \\
\hline 1 & sandy & 2.97 & mean & logarithmic & logarithmic & 26 \\
\hline 2 & carbonate & 1.74 & high & linear & exponential & 7 \\
\hline 3 & sandy & 2.10 & high & linear & exponential & 14 \\
\hline 4 & sandy & 1.24 & low & linear & logarithmic & 8 \\
\hline 5 & sandy & 4.26 & high & linear & logarithmic & 17 \\
\hline 6 & sandy & 4.99 & low & linear & logarithmic & 18 \\
\hline 7 & carbonate & 2.98 & mean & linear & exponential & 22 \\
\hline 8 & sandy & 1.72 & low & logarithmic & logarithmic & 11 \\
\hline 9 & sandy & 2.37 & low & linear & logarithmic & 15 \\
\hline 10 & sandy & 0.98 & mean & linear & logarithmic & 7 \\
\hline 11 & sandy & 4.17 & high & linear & logarithmic & 28 \\
\hline 12 & sandy & 2.65 & mean & logarithmic & exponential & 25 \\
\hline 13 & sandy & 2.48 & mean & logarithmic & logarithmic & 9 \\
\hline 14 & sandy & 1.50 & high & linear & logarithmic & 11 \\
\hline 15 & sandy & 2.24 & high & linear & exponential & 24 \\
\hline 16 & sandy & 1.95 & high & linear & logarithmic & 6 \\
\hline 17 & sandy & 2.01 & high & exponential & logarithmic & 12 \\
\hline 18 & sandy & 1.86 & high & linear & logarithmic & 18 \\
\hline 19 & sandy & 2.01 & high & linear & logarithmic & 13 \\
\hline 20 & sandy & 1.73 & high & linear & logarithmic & 13 \\
\hline 21 & sandy & 3.82 & high & linear & logarithmic & 18 \\
\hline 22 & sandy & 1.39 & high & logarithmic & logarithmic & 35 \\
\hline 23 & sandy & 2.45 & low & linear & exponential & 43 \\
\hline 24 & sandy & 5.25 & mean & logarithmic & logarithmic & 32 \\
\hline 25 & sandy & 4.09 & mean & linear & logarithmic & 32 \\
\hline 26 & sandy & 3.79 & low & logarithmic & logarithmic & 21 \\
\hline 27 & carbonate & 4.80 & low & linear & logarithmic & 9 \\
\hline 28 & carbonate & 15.10 & high & linear & logarithmic & 14 \\
\hline 29 & sandy & 10.47 & mean & logarithmic & exponential & 12 \\
\hline 30 & carbonate & 17.85 & high & logarithmic & exponential & 14 \\
\hline 31 & sandy & 3.98 & high & linear & exponential & 20 \\
\hline 32 & sandy & 2.19 & high & logarithmic & exponential & 20 \\
\hline 33 & sandy & 3.04 & high & linear & logarithmic & 21 \\
\hline 34 & sandy & 1.96 & mean & linear & logarithmic & 13 \\
\hline 35 & sandy & 1.96 & mean & linear & exponential & 9 \\
\hline 36 & sandy & 5.85 & low & linear & logarithmic & 39 \\
\hline 37 & sandy & 2.57 & low & logarithmic & logarithmic & 14 \\
\hline 38 & sandy & 3.07 & high & logarithmic & logarithmic & 13 \\
\hline 39 & sandy & 3.12 & mean & linear & logarithmic & 10 \\
\hline 40 & sandy & 2.63 & low & logarithmic & logarithmic & 11 \\
\hline 41 & sandy & 4.39 & high & logarithmic & exponential & 17 \\
\hline
\end{tabular}


vealing a decrease in level in comparison with that from the previous week (the latter being the "initial level"). Obtained points (described by reference to two values, i.e. weekly recession of groundwater level and initial level) were plotted on a graph prior to the selection of points (from the whole range of volatility of groundwater level) describing maximum recessions in level. A sample of this procedure is shown in Fig. 2. Points specified in the above way were described by means of a regression line, the choice of curve being based on determination coefficients $\left(r^{2}\right)$. Types of ap-

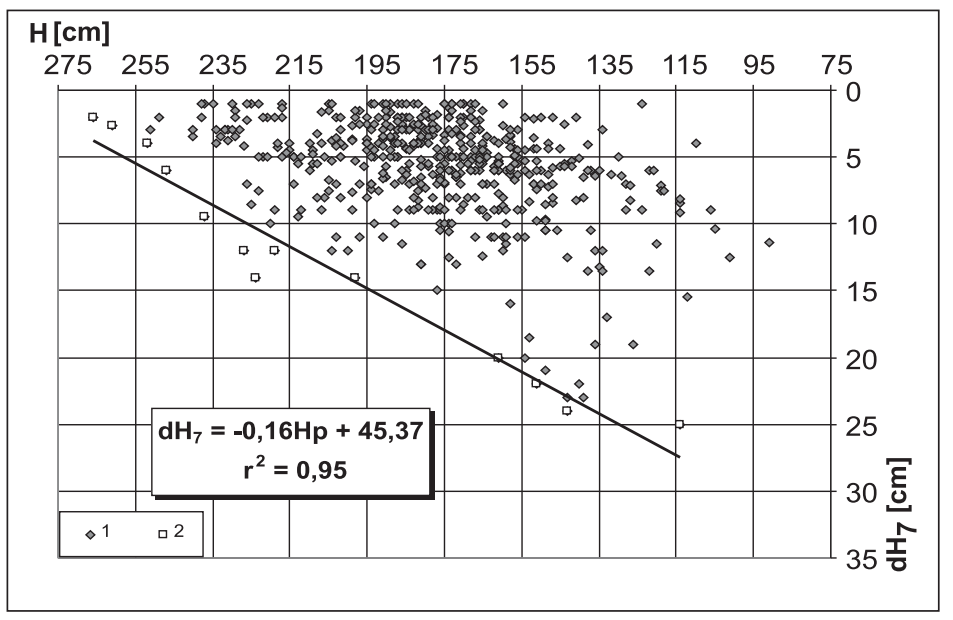

Figure 2. Weekly recessions of groundwater level $\left(\mathrm{dH}_{7}\right)$ as a function of initial level (H). (Exemplified by well no. 18)

1 - weekly recessions

2 - maximum weekly recessions and regression line

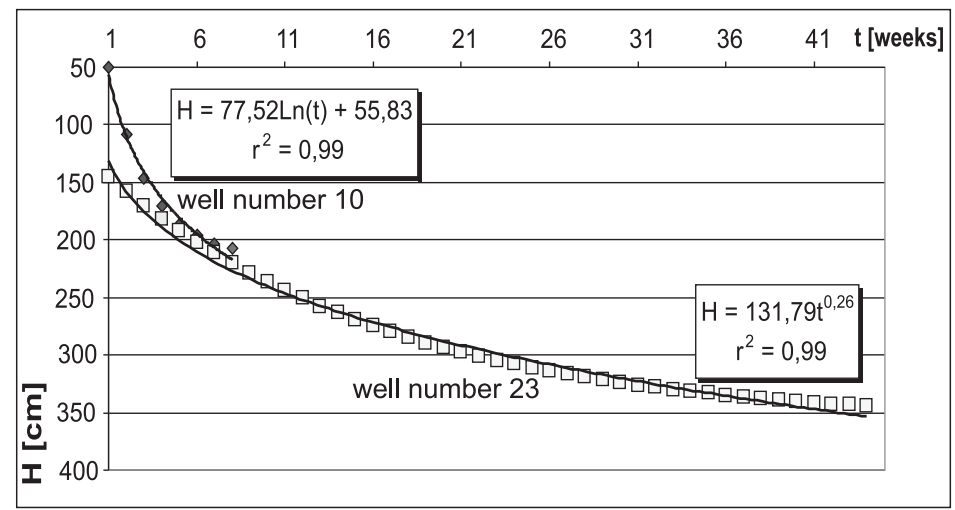

Figure 3. Example of "top speed" recession curve for various sources of water. (Exemplified by wells nos. 10 and 23)

$\mathrm{H}$ - depth of water table

$\mathrm{t}$ - time of recession 
proximated curve for all aquifers examined are as shown in Table 1. Linear and logarithmic functions emerged as most suitable (Fig. 4A).

The said regression lines were used to calculate theoretical weekly maximum recessions of groundwater level between maximum and minimum levels. Subsequent points were obtained by substituting ensuing values to the regression line equation (acquired for the particular groundwater reservoir), beginning with the maximum level value. Water level calculated by this method was then substituted to the equation as an input level. The procedure was repeated until the minimum long-term water level was obtained. On the basis of these points another curve was adjusted (the "top speed" recession curve - Fig. 3 and Table 1). Again, the choice of curve line was made on the basis of the determination coefficient $\left(\mathrm{r}^{2}\right)$. Logarithmic and exponential functions appeared to be the most suitable (Fig. 4B).
Also calculated was the time needed for "top speed" drainage of the groundwater reservoir, starting from the maximum level of water. The speed of this drainage (described in weeks) was established as the number of steps needed to proceed from maximum to minimum groundwater level to estimate the "top speed" recession curve. In the case of almost half of the aquifers, time of "top speed" drainage amounts to approximately four months. However, there were also reservoirs for which the time exceeded nine months (Fig. 4C and Table 1).

\section{RELATIONSHIP BETWEEN CHARACTERISTICS OF MAXIMUM RECESSIONS OF GROUNDWATER LEVEL AND FEATURES OF AQUIFERS}

Studied characteristics of all the examined groundwater reservoirs were compared with geographical characteristics of the basins to find relationships between them. Analyses involved the creation of contin-

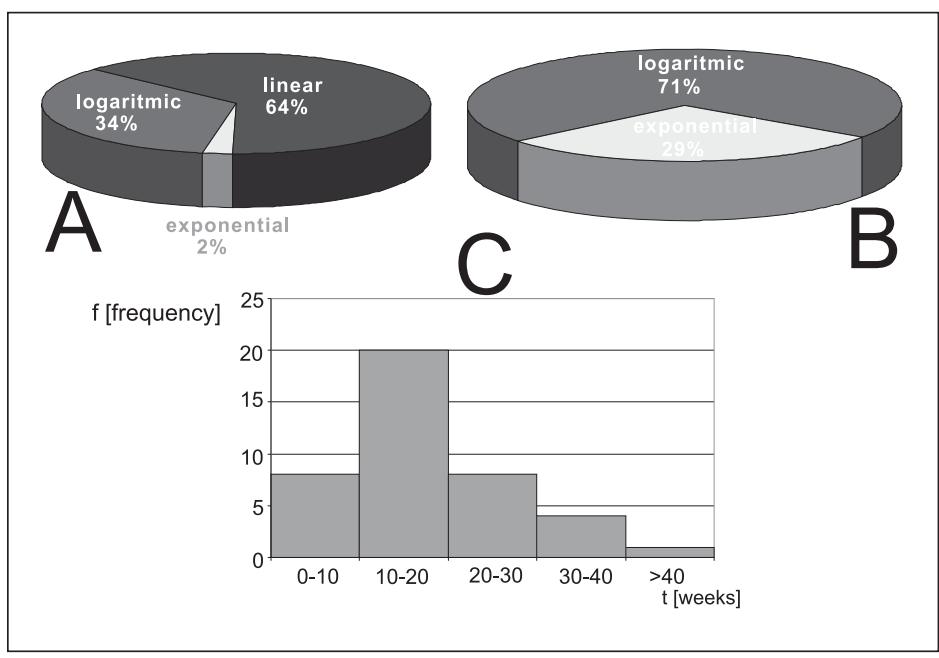

Figure 4. Approximate characteristics of the studied aquifers A - type of regression line for maximum weekly recessions B - type of "top speed" recession curve $\mathrm{C}$ - time of "top speed" drainage from maximum to minimum groundwater level 
gency tables to find relationships between features of the examined sources of groundwater and received functions. Characteristics taken into consideration were:

- geomorphological position,

- depth of water table,

- type of aquifer,

- degree of isolation of groundwater reservoir from the surface.

Potential connections among the studied characteristics were verified by $\chi^{2}$ test on three significance levels $(\alpha=0.1 ; 0.05 ; 0.01)$. The various statistical significance levels adopted to analyse the problem allowed the strength of relationships discovered to be determined, and in the case of weak relationships made it possible to indicate probability of occurrence. If the null hypothesis, concerning the lack of a relationship between examined characteristics, could be rejected at the 0.1 level the relationship was poor; at $\mathrm{p} \leq 0.05$ it was fair and at $\mathrm{p} \leq 0.01$ strong. There is no relationship for which rejection of the null hypothesis is possible.

The analysis shows that a poor relationship exists between isolation of aquifers from the surface and the time needed for "top speed" drainage of groundwater reservoirs. This is understandable, as groundwa- ter level isolation does not have much influence on the drainage of aquifer examined. We may assume that the relationship might be significant where rising groundwater level is concerned, groundwater isolation from the surface being in a position to exert an impact on the speed of precipitation supply.

A fair relationship pertained between the type of regression line for maximum weekly recession and type of aquifer. A linear function was mostly best for groundwater in carbonate rocks, a logarithmic one for sandy aquifers. This means that possible maximum drops in the level in sandy aquifers decrease in proportion to the lowering groundwater level. In the case of reservoirs situated in carbonate rocks, maximum drops in the water table decrease faster, this resulting in non-significant changes in level where low levels of groundwater are concerned. The above information is crucial, as it is the evidence of these reservoirs' water abundance and their resistance to long-lasting shortfalls in supply.

A strong relationship was observed between the depth of the water table and the time needed to achieve "top speed" drainage of groundwater reservoirs. As the two char-

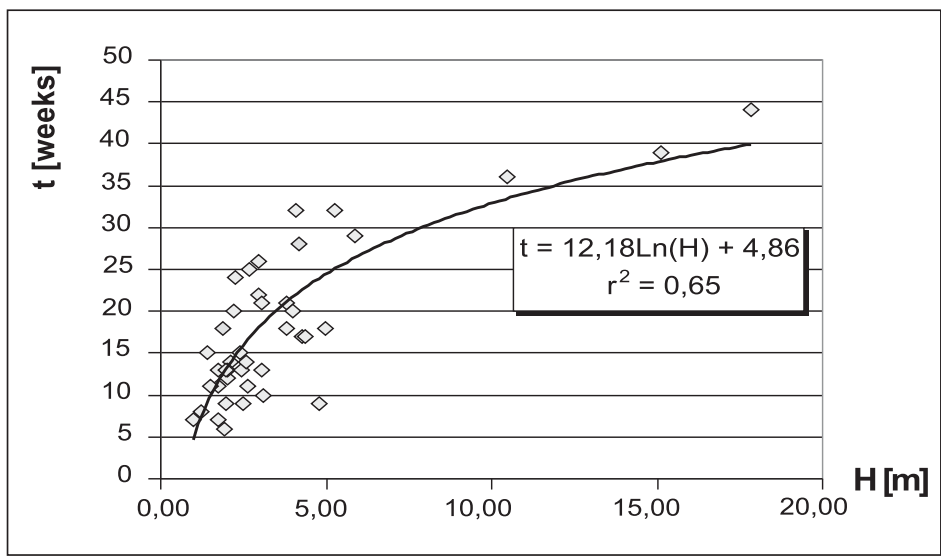

Figure 5. Relationship between depth of water table $(\mathrm{H})$ and time of "top speed" drainage of groundwater reservoir $(t)$ 
acteristics are quantitative features, the relationship between them might be shown as a function (Fig. 5), the best fitting of which appeared to be the logarithmic function, the determination coefficient equalling $65 \%$. In the case of shallow groundwaters the time needed for aquifer drainage changes quite quickly, along with depth to the water table. The time needed to drain a reservoir of depth 1 meter to the water table amounts to 5 weeks, while for reservoirs situated 2.5 meters below the surface that time is as long as 18 weeks. This is obvious, since the shallowest groundwaters are, in most cases, aquifers of limited capacity (with the obvious exception of the waters of river-flooded areas that are abundant alluvial levels). Groundwater levels situated slightly deeper down are usually more abundant. However, it is possible to observe a considerable range of drainage speeds (and at the same time capacities) which is clearly visible at a depth of 5 meters. Deep groundwater levels are characterized by long drainage times of resources, this reflecting their great abundance, and the fact that not all rivers are capable of draining their levels.

\section{CONCLUSIONS}

Analyses indicate that the process of "top speed" drainage of groundwater resources is markedly dependent on the depth to the water table. Reservoirs situated deeper down are less exposed to rapid drainage because of their abundance of water, and the fact that not all rivers are capable of draining them. The means of drainage also depends on the type of aquifer, while the influence of groundwater level isolation from the surface on the speed of the process is not significant. Nevertheless, results presented here are little more than fragmentary, with this work resembling other empirical stud- ies in pertaining only to this particular group of selected measurement points.

The process of groundwater aquifer drainage is undoubtedly a very complex one that depends on numerous factors. However, that should not mean eschewing attempts to become acquainted with the system in question, as it is of great importance to the functioning of river discharge.

\section{ACKNOWLEDGEMENTS}

This research was carried out within the framework of the project entitled "Extreme Hydrometeorological Events in Poland and Their Impacts", as financed by the Ministry of Education and Science (project no. PBZ-KBN-086/P04/2004)

\section{REFERENCES}

Bartnik, A. (2005), Odptyw niski w Polsce [Low Flow in Poland], Łódź, Łódzkie Towarzystwo Naukowe.

Byczkowski, A. (1996), Hydrologia [Hydrology], vol.II, Warszawa, Wydawnictwo Szkoły Głównej Gospodarstwa Wiejskiego (SGGW).

Foster, S.S.D. (1987), Fundamental concepts in aquifer vulnerability, pollution risk and protection strategy, in Van Duijvenbooden, W. and Van Waegeningh, H G, (eds.), Proceedings of the International Conference: Vulnerability of Soil and Groundwater to Pollution, Nordwijk, TNO Committee on Hydrological Research, The Hague, Netherlands.

Gottschalk, L., Tallaksen, L. M., Perzyna, G. (1997), Derivation of Low Flow Distribution Functions Using Recession Curves, Journal of Hydrology, 194, 1-4: 239-262.

Jokiel, P. (2002), Ptytkie wody podziemne $w$ matej zlewni strefy podmiejskiej Ło- 
dzi i ich podatność na zanieczyszczenia obszarowe [The Vulnerability to Pollution of Shallow Groundwater in a Small Drainage Basin Located in the Suburbs of Łódź] in Burchard, J. (ed.), Stan $i$ antropograficzne zmiany jakości wód $w$ Polsce [The Condition of and Anthropogenic Changes to Water Quality in Poland], Łódź, Wydawnictwo Uniwersytetu Łódzkiego, 183-199.

Laaha, G., Blöschl, G. (2005), Low Flow Estimates from Short Stream Flow Records - A Comparison of Methods, Journal of Hydrology, 306, 1-4: 264-286.

Olin, M. (1995), Estimation Of Base Level for an Aquifer From Recession Rates of Groundwater Levels, Hydrogeology Journal, 3, 2: 40-51.

Sawicki, J. (1986), Hydrogeologiczne i geomorfologiczne uwarunkowania wahan zwierciadła wód podziemnych [Hydrogeological and Morphological Conditioning of Groundwater Level Fluctuations], Czasopismo Geograficzne, LVII, vol.4, 493-508.

Tomaszewski, J.T. (1990), Charakter wahania zwierciadła górnego poziomu wód podziemnych [The Character of Fluctuations of the Groundwater Upper Horizon], Wrocław, Wydawnictwo Uniwersytetu Wrocławskiego. 